\title{
Electrochemical Degradation of Reactive Blue 21 and Synthetic Textile Effluent by Using $\mathrm{Co}_{47.5} / \mathrm{C}_{47.5}-\mathrm{PVC}_{5}$ Composite Electrode
}

\author{
Norazzizi Nordin, ${ }^{1,{ }^{*}}$ Mohamad Anis Farith Pisal, ${ }^{1}$ \\ Nur Izzatie Hannah Razman ${ }^{2}$ and Nur Farhana Jaafar ${ }^{1}$ \\ ${ }^{1}$ School of Chemical Sciences, Universiti Sains Malaysia, 11800 Gelugor, Pulau Pinang, Malaysia. \\ ${ }^{2}$ Centre of Foundation Studies, Universiti Teknologi MARA, Selangor Branch, Dengkil Campus, \\ 43800 Dengkil, Selangor, Malaysia. \\ *Corresponding author: E-mail: azzizi@usm.my (+604 653 4030)
}

Received: 11-09-2018

\begin{abstract}
In this study, cobalt/graphite-polyvinyl chloride $\left(\mathrm{Co}_{47.5} / \mathrm{C}_{47.5}-\mathrm{PVC}_{5}\right)$ composite electrode was fabricated by mechanical alloying technique. The fabricated electrode and graphite rod were used as anode and cathode, respectively, in the decolourisation of aqueous C. I. Reactive Blue 21 (RB21) and synthetic textile effluent, containing a mixture of azo and anthraquinone dyes. The fabricated electrode showed high efficiency in the decolorisation of aqueous RB21 (99.95\%) and synthetic textile effluent. This is further confirmed by the high reduction percentage $(>75 \%)$ of $\mathrm{COD}$ and $\mathrm{BOD}_{5}$ for both treated samples. The elemental composition study by using FESEM-EDX showed no significant changes in the composition of elements $(\mathrm{C}, \mathrm{Co}$ and $\mathrm{Cl})$ in the freshly fabricated electrode and after electrolysis of synthetic textile effluent. This showed that the fabricated electrode has a high mechanical strength and strong binding ability between $\mathrm{C}$ and Co due to the use of PVC as a binder.
\end{abstract}

Keywords: Composite electrode; decolorisation; electrochemical technique; C. I. Reactive Blue 21; synthetic textile effluent

\section{Introduction}

Synthetic dyes are among the most widely used pollutants in various industries, including textiles, paper, food and cosmetics. In line with the increase in usage by various industries, more than 100000 synthetic dyes with different structures are synthesised and more than 0.7 million tonnes of dyestuffs are produced throughout the year. ${ }^{1}$ Synthetic dyes are categorised into several groups, depending on their applications (dyeing method) such as reactive dyes, basic dyes, acid dyes, vat dyes, mordant dyes, and disperse dyes. It also depends on their chemical structure, such as azo dyes, anthraquionone dyes, triphenylmethane dyes, and phthalocyanine dyes. ${ }^{2}$

In the textile industry, only $60 \%-90 \%$ of the dyes used are fixed to textile fibre while the other $10 \%-40 \%$ may remain unfixed to the fibre and will be released into the effluent. ${ }^{3}$ This has an adverse effect on aquatic ecosystems due to the presence of synthetic dyes even in small quantities $\left(<1 \mathrm{mg} \mathrm{L}^{-1}\right)$. They can be seen with the naked eye and have negatively affected the aesthetic quality and transparency of lakes, rivers, and others. ${ }^{4}$ This in turn resulted in the destruction of aquatic ecosystems and the formation of dead deoxygenated zones in seas and oceans. ${ }^{5}$ Therefore, the treatment of dye containing effluents is very important to reduce the negative effects on aquatic life.

Various strategies were reported on the treatment of textile effluents. They are classified into biological methods (enzymes and microorganisms), physical methods (filtration, flocculation, and adsorption), and oxidation methods (advanced oxidation and chemical oxidation), ${ }^{6,7}$ However, today the use of electrochemical oxidation technique in textile wastewater treatment is getting more attention as this method does not involve the use of additional chemicals. ${ }^{8.9}$ Previous studies have shown that this technique provided high efficiency in the removal of organic and inorganic pollutants from the effluents. ${ }^{10,11,12}$ According to Najafpoor et al., this technique requires simple equipment, easy implementation, and on-site treatment in less space. ${ }^{13}$ 
In the electrochemical treatment of industrial effluents, anode plays an important role as it acts as a site for electrochemical reactions. The material for electrode fabrication plays a major role in determining the efficiency and reactivity of the prepared electrode in an electrochemical reaction. Various electrodes were used in the treatment of synthetic dyes and textile industrial effluents, such as $\mathrm{Pt},{ }^{14-16}$ boron-doped diamond (BDD), ${ }^{17-19}$ and dimensionally stable anodes (DSA). ${ }^{20-22}$ In the current study, metal/graphite composite electrodes were prepared by mixing two different material (metal and graphite) powders with polyvinyl chloride (PVC). It is expected that the electrode performance in the electrochemical reaction will increase as the existence of two different materials in an electrode provides better synergistic effects and active bifunctional catalyst. ${ }^{4}$

The main objective of this study is to investigate the efficiency of $\mathrm{Co}_{47.5} / \mathrm{C}_{47.5}-\mathrm{PVC}_{5}$ composite electrode in the decolourisation of aqueous RB21 and synthetic textile effluents. The effect of electrolysis conditions was also examined in the current study by investigating the effect of metal:graphite ratio in the prepared electrode, supporting electrolyte concentration, applied voltage, and electrolysis time on RB21 decolourisation. The surface characterisation of the prepared composite electrode was also performed in this study by using FESEM, EDX, and gas sorption analyser.

\section{Experimental}

\section{1. Chemicals}

All the chemicals used were of analytical research (AR) grade. Tin $(\mathrm{Sn})$, copper $(\mathrm{Cu})$, cobalt $(\mathrm{Co})$, and aluminium (Al) powder with $99.9 \%$ purity were purchased from Aldrich. Sodium chloride $(\mathrm{NaCl})$ solution, which acts as a supporting electrolyte in the electrolysis process, was purchased from $\mathrm{R} \& \mathrm{M}$ Chemicals. In this study, C. I. Reactive Blue 21 (RB21), C. I. Reactive Blue 19 (RB19), C. I. Reactive Violet 5 (RV5), and C. I. Reactive Red 198 (RR198) (Figure 1) were used as synthetic dyes and purchased from Dylon. Besides, polyvinyl chloride (PVC) and graphite powder $(\mathrm{C})$ were obtained from BDH Ltd. whereas tetrahydrofuran (THF) was obtained from Systerm.

\section{2. Preparation of Metal/Graphite-PVC Composite Electrode}

The anode was prepared by mixing $0.475 \mathrm{~g}$ of metal powder ( $\mathrm{Sn}, \mathrm{Cu}, \mathrm{Al}$, or $\mathrm{Co}$ ) with $0.475 \mathrm{~g}$ of graphite (C) powder ( $\mathrm{M}: \mathrm{C}$ is 50:50 (wt. \%), in which $\mathrm{M}=$ metal) and 0.05 $\mathrm{g}$ of PVC as a binder by using a mechanical alloying technique (MAT). ${ }^{4}$ The ratio of metal and $\mathrm{C}$ powders to $\mathrm{PVC}$ was 95:5 PVC (wt. \%). Then, $4 \mathrm{~mL}$ of THF was used to dissolve the PVC. The mixture was stirred until homogenous and oven dried at $100{ }^{\circ} \mathrm{C}$ for $2 \mathrm{~h}$. The mixture was placed in a stainless-steel mould of $1 \mathrm{~cm}$ diameter and pressed at $10^{4}$ $\mathrm{kg} \mathrm{cm}^{-2}$. The pellet obtained (approximately $1.5 \mathrm{~g}$ ) was then connected to a silver wire with silver conducting paint (Sigma-Aldrich) and sealed in a glass rod. Subsequently, epoxy resin (Devcon) was applied to cover the silver wire connecting surface. The metal/graphite-PVC composite electrode was used in the decolourisation of RB21 solution.

\section{3. Preparation of Aqueous RB21 and Synthetic Textile Effluent}

In this study, two types of samples were used, namely aqueous RB21 and synthetic textile effluent. The RB21

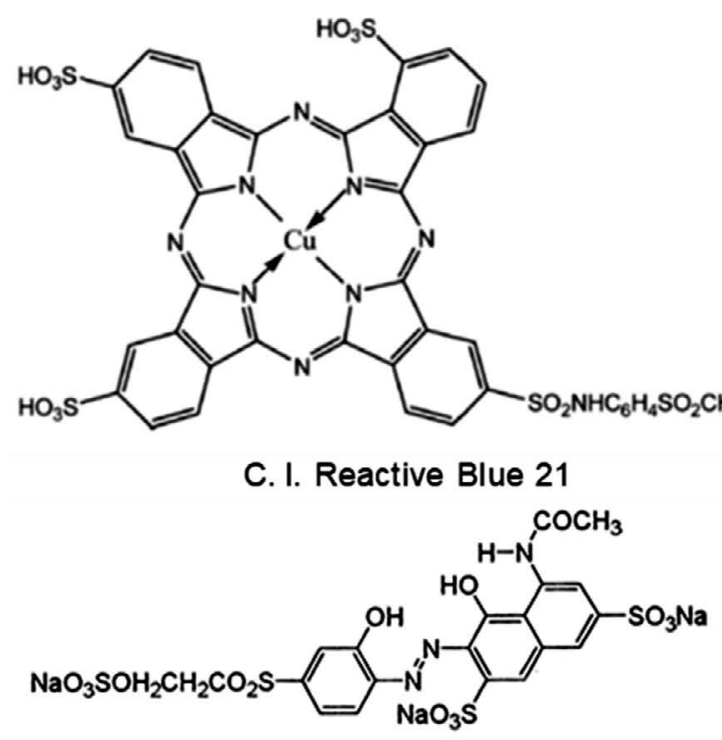

C. I. Reactive Violet 5<smiles>CS(=O)(=O)c1ccc(N=Nc2c([N+](=O)[O-])cc3cc(S(=O)(=O)O[Na])cc(Nc4nc(Cl)nc(Nc5cccc(S(=O)(=O)O[Na])c5)n4)c3c2O)cc1</smiles>

C. I. Reactive Red 198

Figure 1. Structures of RB21, RB19, RV5, and RR198. 
solution was prepared by dissolving a certain amount of RB21 in deionised water. Synthetic textile effluent was prepared by dissolving equal amount of RB21, RB19, RV5, and RR198 in tap water along with the other chemical additives, as described by Verma et al. ${ }^{23}$

\section{4. Decolourisation of Aqueous RB21 and Synthetic Textile Effluent}

The electrolysis of aqueous RB21 was performed by using a two-electrode system, which consisted of an anode (metal/graphite-PVC composite electrode) and a cathode (graphite rod electrode), with $\mathrm{NaCl}$ solution as a supporting electrolyte. Prior to electrolysis, both anode and cathode were rinsed with distilled water and a small amount of acetone. A direct current (DC) power supply (TTi PSU Bench CPX 400) and stirrer hotplate with magnetic bar were used throughout the electrolysis process. The electrochemical cell used was a simple and undivided cell made of Pyrex glass with a capacity of $250 \mathrm{~mL}$. The electrodes were placed vertically and parallel to each other in the electrochemical cell, with a constant gap between electrodes at approximately $20 \mathrm{~mm}$. The electrolysis of synthetic textile effluent was carried out by using similar procedures, as described above. The same anode from the previous electrolysis of aqueous RB21 was used in the electrolysis of synthetic textile effluent.

\section{5. Optimisation of Electrolysis Parameters for the Decolourisation of Aqueous RB21}

Optimisation of electrolysis parameters was carried out by optimising the ratio of metal and $\mathrm{C}$ in the prepared electrode, supporting electrolyte concentration, electrolysis time and applied voltage. For the optimisation of metal and $\mathrm{C}$ ratio in the prepared electrode, the ratio and mass of metal, C, and PVC are summarised in Table 1. The procedure for preparation of anodes is similar as mentioned in Section 2.2.

\subsection{Instrumentation}

To observe the decolourisation level of aqueous RB21 and synthetic textile effluent, the sample solution was characterised by using an UV-Vis (Perkin Elmer Lambda 35) spectrometer in the range of $200-900 \mathrm{~nm}$ by using $10 \mathrm{~mm}$ quartz cuvettes. The surface properties of the electrode were determined by using gas sorption analyser (ASAP 2020 V4.010). Brunauer-Emmett-Teller (BET) method was used to determine the surface area of the electrode. BJH model was used to calculate the pore size. Surface morphology of the electrode was observed by using Field Emission Scanning Electron Microscope (FESEM) (Leo Supra $50 \mathrm{VP}$ ). The elemental composition of prepared electrode was determined by using Energy Dispersive X-ray (EDX) spectrometer. The size and shape of the particles were observed by using a transmission electron microscopy (TEM) (Philips CM12-12796) with an accelerating voltage of $100 \mathrm{kV}$. Samples were prepared on carbon-coated copper grids covered with a polyvinyl formal polymer by adding a drop onto the grid and evaporating the solvent (ethanol) in ambient condition.

\section{7. Analytical Measurement}

Decolourisation of aqueous RB21 was determined based on the original concentration of RB21 $\left(c_{i}\right)$ and RB21 concentration after electrolysis process $\left(c_{t}\right)$ by measuring absorbance at the wavelength of $624 \mathrm{~nm}$ in the Vis region of RB21. Measurement of RB21 absorbance was performed by using UV-Vis spectrophotometer. Decolourisation was calculated in percentage (\%) as in the following equation:

$$
\text { Decolourisation }(\%)=\left(\frac{\mathrm{C}_{i}-\mathrm{C}_{t}}{\mathrm{c}_{i}}\right) \times 100 \%
$$

The absorbance versus RB21 concentrations graph in the range of 10 to $110 \mathrm{mg} \mathrm{L}^{-1}$ is a linear graph referring to the following equation:

$$
\text { Absorbance }=0.015 c+0.033\left(R^{2}=0.996\right)
$$

Where $c$ represents the concentration of RB21 solution in $\mathrm{mg} \mathrm{L}^{-1}$ unit.

\section{8. Reduction of $\mathrm{COD}$ and $\mathrm{BOD}_{5}$}

Chemical Oxygen Demand (COD) and Biochemical Oxygen Demand $\left(\mathrm{BOD}_{5}\right)$ were performed on an aqueous RB21 and synthetic textile effluent before and after electrolysis by using the prepared electrode. Standard methods

Table 1. The composition ratio and mass of $\mathrm{Co}, \mathrm{C}$, and $\mathrm{PVC}$ for the preparation of Co/C-PVC electrodes.

\begin{tabular}{lcccc}
\hline Electrode & Co:C ratio (\%) & Mass of Co $(\mathbf{g})$ & Mass of C $(\mathbf{g})$ & Mass of PVC $(\mathbf{g})$ \\
\hline $\mathrm{Co}_{95.0} / \mathrm{C}_{0.0}-\mathrm{PVC}_{5}$ & $100: 0$ & 0.950 & - & 0.05 \\
$\mathrm{Co}_{66.5} / \mathrm{C}_{28.5}-\mathrm{PVC}_{5}$ & $70: 30$ & 0.665 & 0.285 & 0.05 \\
$\mathrm{Co}_{47.5} / \mathrm{C}_{47.5}-\mathrm{PVC}_{5}$ & $50: 50$ & 0.475 & 0.475 & 0.05 \\
$\mathrm{Co}_{28.5} / \mathrm{C}_{66.5}-\mathrm{PVC}_{5}$ & $30: 70$ & 0.285 & 0.665 & 0.05 \\
$\mathrm{Co}_{0.0} / \mathrm{C}_{95.0}-\mathrm{PVC}_{5}$ & $0: 100$ & - & 0.950 & 0.05 \\
\hline
\end{tabular}


508B and 507 were used for the $\mathrm{COD}$ and $\mathrm{BOD}_{5}$ analyses, respectively, as described by the American Public Health Association (APHA 1981). ${ }^{24}$

\subsection{Statistical Analysis}

The data were expressed as mean \pm standard error (SE) with at least three times replication. The statistical analysis was carried out by using Statistical Package for Social Sciences (SPSS) Version 17.0 with one-way ANOVA. The data obtained were considered as statistically significant when the value of $p<0.05$.

\section{Results and Discussion}

\section{1. Preliminary Experiment}

Four types of metal/graphite-PVC composite electrodes were prepared and used in the preliminary experiment to investigate the efficiency of the prepared electrodes in the decolourisation of RB21 solution. This was to identify the best metal-graphite mixture that could give a maximum decolourisation of aqueous RB21. The results in Figure 2 show that maximum decolourisation percentage

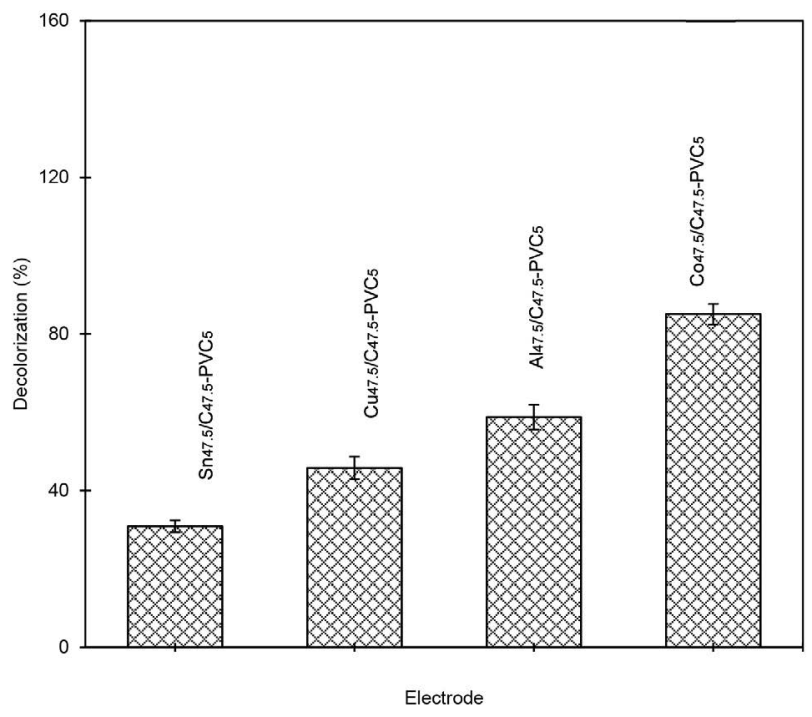

Figure 2. Decolourisation percentage of aqueous RB21 after electrolysis by using different types of metal/graphite-PVC composite electrodes. $\left.[\mathrm{RB} 21]_{\mathrm{o}}=50 \mathrm{mg} \mathrm{L}^{-1} ; \mathrm{NaCl}\right]=1.0 \mathrm{~mol} \mathrm{~L}^{-1} ; E=5 \mathrm{~V} ; I=$ $0.62 \mathrm{~A} ; t=15 \mathrm{~min}$.

(85.09\%) of $\mathrm{RB} 21$ is obtained by using $\mathrm{Co}_{47.5} / \mathrm{C}_{47.5}-\mathrm{PVC}_{5}$ electrode compared to other metal/graphite-PVC composite electrodes. This showed that the mixture of Co and $\mathrm{C}$ in the $\mathrm{Co}_{47.5} / \mathrm{C}_{47.5}-\mathrm{PVC}_{5}$ electrode showed the best synergistic effect with a maximum decolourisation percentage as compared to other electrodes. Therefore, this electrode will be used in the optimisation of electrolysis parameters for the decolourisation of aqueous RB21.

\section{2. Optimisation of Electrolysis Parameters for the Decolourisation of Aqueous RB21}

Figure 3a shows the percentage of decolourisation on $\mathrm{RB} 21$ by using $\mathrm{Co} / \mathrm{C}-\mathrm{PVC}$ electrodes with different Co: $\mathrm{C}$ ratios (100:0, 70:30, 50:50, 30:70, 0:100). The electrode with a composition ratio of 50:50 (known as $\mathrm{Co}_{47.5} /$ $\mathrm{C}_{47.5}-\mathrm{PVC}_{5}$ electrode) exhibited the highest percentage of decolourisation, which was $85.27 \%$ as compared to other electrodes. This showed that the ratio of $\mathrm{Co}$ and $\mathrm{C}$ in the electrode provided better efficiency for RB21 removal. The composition ratio of 100:0 and 70:30 (known as $\mathrm{Co}_{95.0} /$ $\mathrm{C}_{0.0}-\mathrm{PVC}_{5}$ and $\mathrm{Co}_{66.5} / \mathrm{C}_{25.5}-\mathrm{PVC}_{5}$ electrodes, respectively) gave almost equal percentage of decolourisation (84.8\% and $82.5 \%$, respectively) as the decolourisation percentage obtained for 50:50 ratio. However, the use of more Co powder in both electrodes can increase the operating costs. Therefore, the electrode with a 50:50 ratio $\left(\mathrm{Co}_{47.5} /\right.$ $\mathrm{C}_{47.5}-\mathrm{PVC}_{5}$ electrode) was considered as an optimum electrode based on the highest RB21 decolourisation percentage achieved in this study with less Co used in the preparation of the electrode.

Figure $3 \mathrm{~b}$ shows the effect of the supporting electrolyte concentration on the decolourisation of RB21 solution. The supporting electrolyte ( $\mathrm{NaCl}$ solution) was added in the electrochemical system to modify the electrochemical conductivity and facilitate the electrical current flow. 4,25 The presence of chloride ions from the addition of $\mathrm{NaCl}$ can lead to active oxidant formations, such as chlorine, hypochlorous acid, and/or hypochlorite, depending on the $\mathrm{pH}$ (Equations 3-5). These active oxidants are beneficial in the oxidation of organic pollutants at the anode or/and in bulk solution (Equation 6). ${ }^{8}$

$$
\begin{aligned}
& 2 \mathrm{Cl}^{-} \rightarrow \mathrm{Cl}_{2}+2 \mathrm{e}^{-} \\
& \mathrm{Cl}_{2}+\mathrm{H}_{2} \mathrm{O} \rightarrow \mathrm{HOCl}+\mathrm{H}^{+}+\mathrm{Cl}^{-} \\
& \mathrm{HOCl} \rightarrow \mathrm{H}^{+}+\mathrm{OCl}^{-} \\
& \text {Organics }+\mathrm{OCl}^{-} \rightarrow \text { intermediates } \\
& \rightarrow \mathrm{CO}_{2}+\mathrm{Cl}^{-}+\mathrm{H}_{2} \mathrm{O}
\end{aligned}
$$

As shown in Figure 3b, the percentage of decolourisation increased from $74.57 \%$ to $87.45 \%$ with the concentration of $\mathrm{NaCl}$ from $0.01 \mathrm{~mol} \mathrm{~L}^{-1}$ to $2.0 \mathrm{~mol} \mathrm{~L}^{-1}$, respectively, after $15 \mathrm{~min}$ of electrolysis. Plus, electrolysis by using $0.5 \mathrm{~mol} \mathrm{~L}^{-1}$ and $2.0 \mathrm{~mol} \mathrm{~L}^{-1} \mathrm{NaCl}$ resulted in almost equal percentage of decolourisation $(85.09 \%$ and $85.27 \%$, respectively). In addition, application of higher concentration of electrolyte (in this case $1.0 \mathrm{~mol} \mathrm{~L}^{-1}$ and above) resulted in electrode damage and heat production.

As shown in Equations 3-6, the increased $\mathrm{NaCl}$ concentration has increased the electrogenerated $\mathrm{OCl}^{-}$anions. This electrode corrosion was also due to the presence of $\mathrm{OCl}^{-}$ions in the electrolysis solution. This was reported 
a)

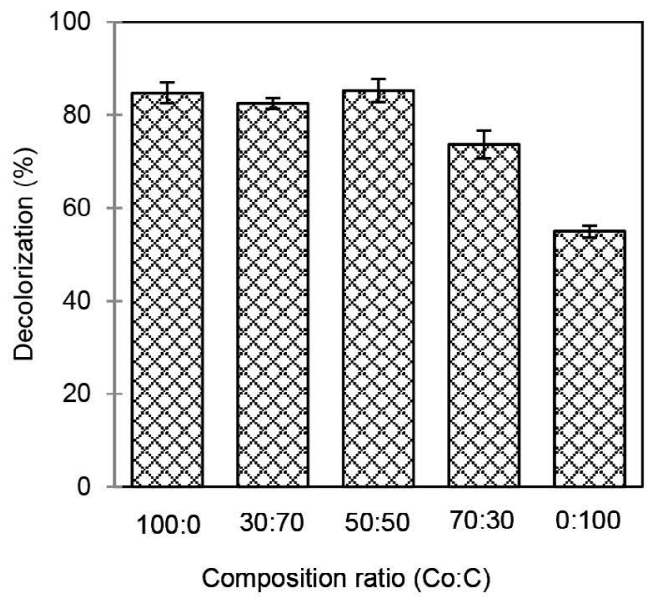

c)

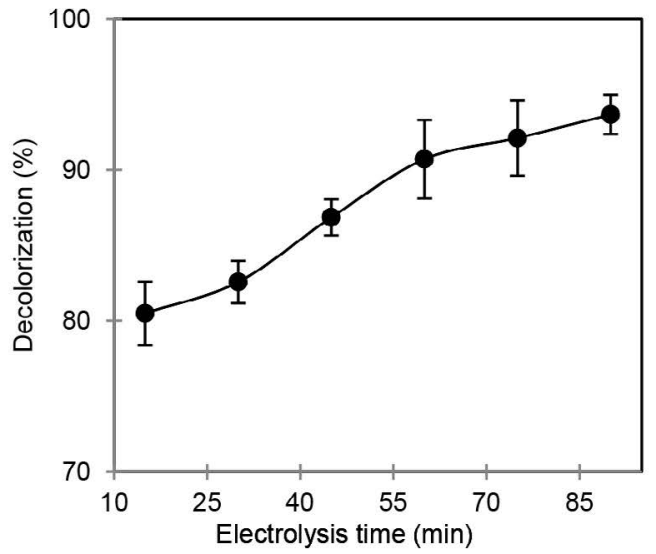

b)

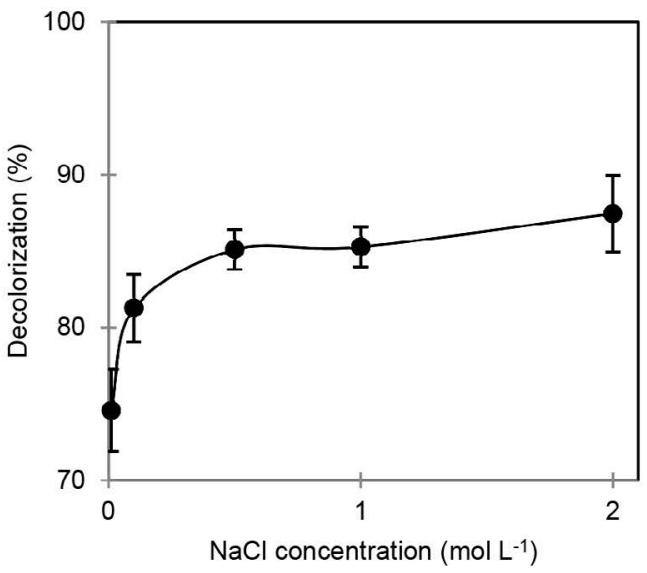

d)

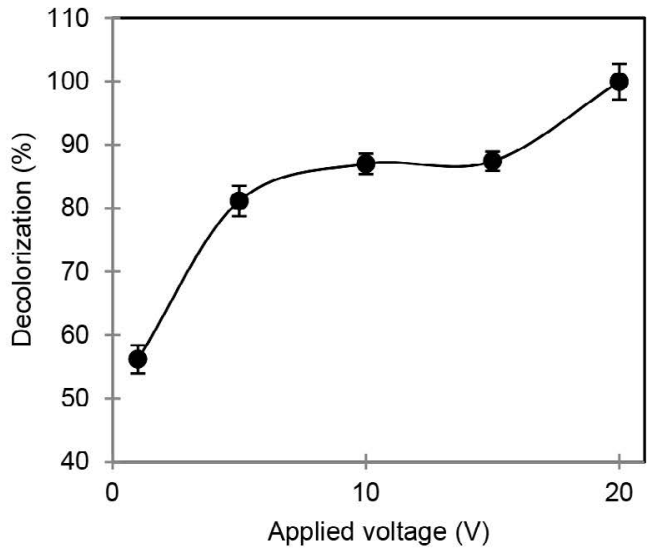

Figure 3. Decolourisation percentage of aqueous RB21 by using different (a) Co:C ratio in the prepared electrode $\left([\mathrm{RB} 21]_{\mathrm{o}}=50 \mathrm{mg} \mathrm{L}-1\right.$; $[\mathrm{NaCl}]=$ $\left.1.0 \mathrm{~mol} \mathrm{~L}^{-1} ; E=5 \mathrm{~V} ; I=0.62 \mathrm{~A} ; t=15 \mathrm{~min}\right) ;\left(\right.$ b) $\mathrm{NaCl}$ concentration ( $[\mathrm{RB} 21]_{\mathrm{o}}=50 \mathrm{mg} \mathrm{L}^{-1} ; I=0.02-1.12 \mathrm{~A}$ (for $\left.0.01-2.0 \mathrm{~mol} \mathrm{~L} \mathrm{NaCl}^{-1}\right) ; E=5 \mathrm{~V} ; t$ $=15 \mathrm{~min}$; anode $\left.=\mathrm{Co}_{47.5} / \mathrm{C}_{47.5}-\mathrm{PVC}_{5}\right) ;(\mathrm{c})$ electrolysis time $\left([\mathrm{RB} 21]_{\mathrm{o}}=50 \mathrm{mg} \mathrm{L}^{-1} ;[\mathrm{NaCl}]=0.5 \mathrm{~mol} \mathrm{~L}^{-1} ; E=5 \mathrm{~V} ; I=0.36 \mathrm{~A} ;\right.$ anode $=\mathrm{Co}_{47.5} / \mathrm{C}_{47.5^{-}}$ $\left.\mathrm{PVC}_{5}\right) ;(\mathrm{d})$ applied voltage $\left([\mathrm{RB} 21]_{\mathrm{o}}=50 \mathrm{mg} \mathrm{L}^{-1} ;[\mathrm{NaCl}]=0.5 \mathrm{~mol} \mathrm{~L}-1 ;=45 \mathrm{~min} ; I=0.06-0.93 \mathrm{~A}\right.$ (for $\left.1-20 \mathrm{~V}\right) ;$ anode $\left.=\mathrm{Co}_{47.5} / \mathrm{C}_{47.5}-\mathrm{PVC}_{5}\right)$.

by several researchers in previous studies. ${ }^{26-28}$ According to Galvan-Martinez et al., ${ }^{26} \mathrm{OCl}^{-}$ions are corrosive to some elements. This resulted in the corrosion of $\mathrm{Co}_{47.5} /$ $\mathrm{C}_{47.5}-\mathrm{PVC}_{5}$ electrode surface after electrolysis of RB21 by using $\mathrm{NaCl}$ electrolytes. Therefore, $0.5 \mathrm{~mol} \mathrm{~L}^{-1}$ was considered as an optimum concentration of $\mathrm{NaCl}$ for the decolourisation of RB21 with $85.09 \%$ of RB21 decolourisation percentage.

The effect of electrolysis time on the decolourisation percentage of RB21 was investigated in the range of $15 \mathrm{~min}$ to $90 \mathrm{~min}$. The increase in electrolysis time from this study showed an increased decolourisation percentage of up to 93.67\% (Figure 3c). Due to the increase in generation of $\mathrm{OCl}^{-}$ions in the bulk solution resulting from the longer electrolysis time, better RB21 decolourisation efficiency was obtained as compared to a shorter electrolysis time. Electrolysis by using $60 \mathrm{~min}$ to $90 \mathrm{~min}$ leads to the electrode damage and corrosion of anode materials into the bulk solution. Due to the anode corrosion, precipitate was formed at the end of the electrolysis process and mixed with the electrolysis product. At $45 \mathrm{~min}$, the electrode showed its ability to decolourise the aqueous RB21 without the formation of precipitate at the end of the electrolysis. Therefore, $45 \mathrm{~min}$ was considered as an optimum electrolysis time, with $86.87 \%$ of RB21 decolourisation percentage.

The decolourisation efficiency was significantly affected by the applied voltage which was studied in the range of 1 $\mathrm{V}$ to $20 \mathrm{~V}$. In Figure 3d, increasing the applied voltage from $1 \mathrm{~V}$ to $20 \mathrm{~V}$ increased the percentage of RB21 decolourisation after $45 \mathrm{~min}$ of electrolysis from $56.20 \%$ to $99.95 \%$, respectively. Again, this was due to the increased generation of $\mathrm{OCl}^{-}$species by the application of high value of applied voltage. Therefore, $20 \mathrm{~V}$ of applied voltage was considered as an optimum value of applied voltage based on the complete decolourisation of RB21 obtained in Figure 3d.

\section{3. Decolourisation of Aqueous RB21}

Figure 4 shows the UV-Vis spectra obtained for 50 $\mathrm{mg} \mathrm{L}^{-1}$ of RB21 in $0.5 \mathrm{~mol} \mathrm{~L}^{-1} \mathrm{NaCl}$ by using the optimum electrolysis parameters as obtained in the previous Section 


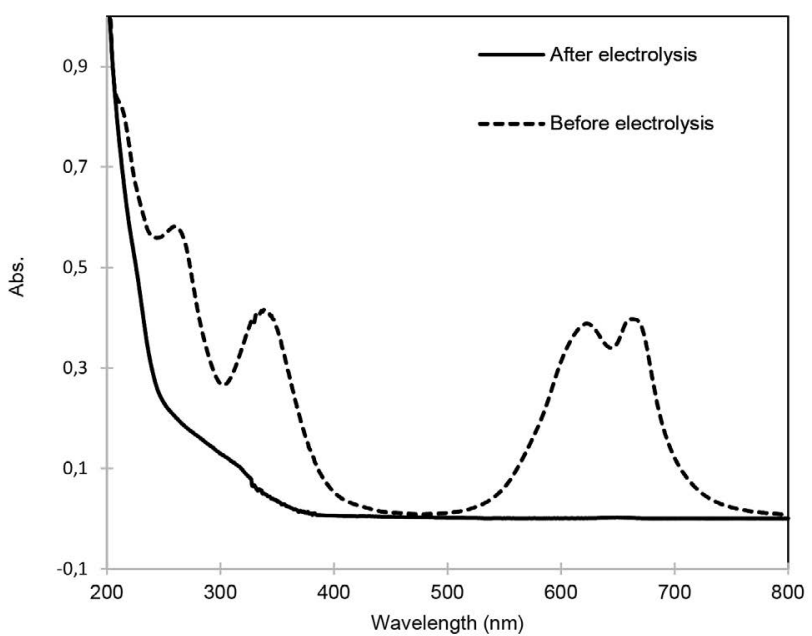

Figure 4. UV-Vis spectra of aqueous RB21 before and after electrochemical treatment by using $\mathrm{Co}_{47.5} \mathrm{C}_{47.5}-\mathrm{PVC}$ composite electrode. $\left([\mathrm{RB} 21]_{\mathrm{o}}=50 \mathrm{mg} \mathrm{L}^{-1} ;[\mathrm{NaCl}]=0.5 \mathrm{~mol} \mathrm{~L}^{-1} ; t=45 \mathrm{~min} ; E=20 \mathrm{~V} ; I\right.$ $=0.93 \mathrm{~A})$.

(3.2). The initial spectra $(0 \mathrm{~min})$ showed the appearance of three peaks at the wavelength of $339 \mathrm{~nm}$ in the UV region, and $624 \mathrm{~nm}$ and $663 \mathrm{~nm}$ in the visible region. The peak at $663 \mathrm{~nm}$ exhibited maximum absorption and was selected for subsequent study. ${ }^{29,30}$ The spectra obtained after 45 min of electrolysis showed the disappearance of all peaks after the electrolysis process. This suggested that the complex structure of RB21 was completely destroyed by the electrochemical process, and a colourless solution was produced after the electrolysis.

\section{4. Decolourisation of Synthetic Textile Effluent}

Optimum electrolysis conditions obtained in Section 3.2 were also applied in the decolourisation of synthetic textile effluent. This was to determine the efficiency of $\mathrm{Co}_{47.5} / \mathrm{C}_{47.5}-\mathrm{PVC}_{5}$ electrode in the degradation of various types of structurally different dyes and other pollutants. Figure 5 shows the UV-Vis spectra obtained for synthetic textile effluent before and after electrolysis. For untreated effluents $(0 \mathrm{~min})$, three peaks were observed at the wavelengths of $337 \mathrm{~nm}$ in the UV region, and $626 \mathrm{~nm}$ and $667 \mathrm{~nm}$ in the visible region. After $45 \mathrm{~min}$ of electrol- ysis with an applied voltage of $20 \mathrm{~V}$ in the presence of 0.5 mol L ${ }^{-1}$ of $\mathrm{NaCl}$ as a supporting electrolyte, the previous peaks completely disappeared. The colour of dyes mixture solution changes from blackish blue to colourless solution at the end of the electrolysis. It proved that the electrochemical treatment by using $\mathrm{Co}_{47.5} / \mathrm{C}_{47.5}-\mathrm{PVC}_{5}$ electrode was able to degrade the pollutants contained in the effluent.

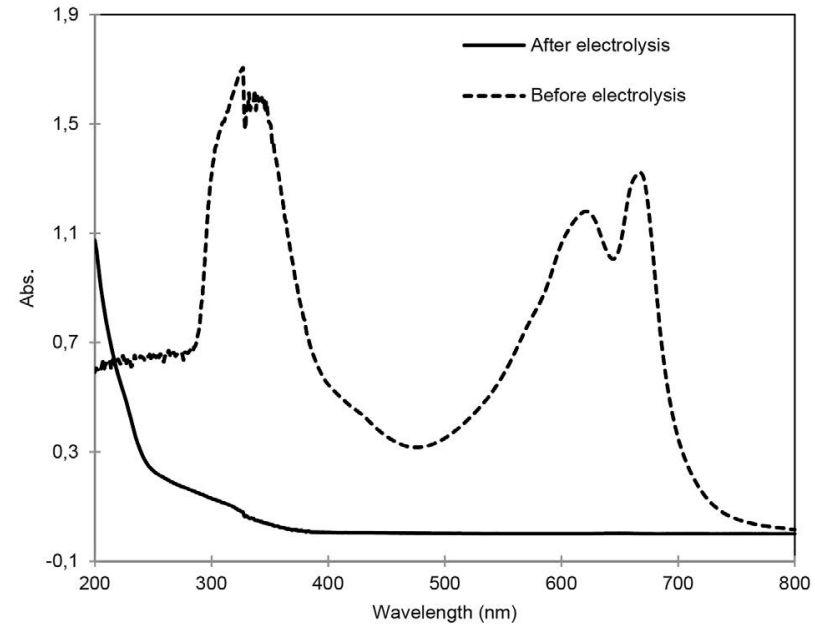

Figure 5. UV-Vis spectra for synthetic textile effluent before and after electrochemical treatment by using $\mathrm{Co}_{47.5} / \mathrm{C}_{47.5}-\mathrm{PVC}_{5}$ electrode. $\left([\mathrm{NaCl}]=0.5 \mathrm{~mol} \mathrm{~L}^{-1} ; t=45 \mathrm{~min} ; E=20 \mathrm{~V} ; I=0.93 \mathrm{~A}\right)$.

\section{5. Reduction of $\mathrm{COD}$ and $\mathrm{BOD}_{5}$}

The results for $\mathrm{COD}$ and $\mathrm{BOD}_{5}$ analyses of treated and untreated aqueous RB21 and synthetic textile effluent are summarised in Table 2. In addition to the colour removal, the electrochemical treatment by using the $\mathrm{Co}_{47.5} /$ $\mathrm{C}_{47.5}-\mathrm{PVC}_{5}$ electrode could also significantly reduce the $\mathrm{COD}$ and $\mathrm{BOD}_{5}$ (Table 2). Table 2 also shows that the removal percentages of $\mathrm{COD}$ and $\mathrm{BOD}_{5}$ for the synthetic textile effluents were lower than for the RB21 solution. This was due to the presence of more organic and inorganic compounds in synthetic textile effluents that created more challenging conditions for the $\mathrm{COD}$ and $\mathrm{BOD}_{5}$ removal, resulting in lower $\mathrm{COD}$ and $\mathrm{BOD}_{5}$ removal percentage than for the aqueous RB21.

Table 2. $\mathrm{COD}, \mathrm{BOD}_{5}$, and $\mathrm{pH}$ of untreated and treated $50 \mathrm{mg} \mathrm{L}^{-1} \mathrm{RB} 21$ solution and synthetic textile effluent by using $\mathrm{Co}_{47.5} /$ $\mathrm{C}_{47.5}-\mathrm{PVC}_{5}$ electrode. $\left([\mathrm{NaCl}]=0.5 \mathrm{~mol} \mathrm{~L}^{-1}, E=20 \mathrm{~V}, t=45 \mathrm{~min}\right)$.

\begin{tabular}{lcccc}
\hline Sample & Analysis & Untreated & Treated & Removal (\%) \\
\hline RB21 solution & $\mathrm{COD}\left(\mathrm{mg} \mathrm{L}^{-1}\right)$ & $182.4 \pm 7.1$ & $15.5 \pm 8.5$ & $91.5 \pm 6.0$ \\
& $\mathrm{BOD}_{5}\left(\mathrm{mg} \mathrm{L}^{-1}\right)$ & $56.8 \pm 6.7$ & $10.7 \pm 8.3$ & $81.2 \pm 5.7$ \\
Synthetic textile effluent & $\mathrm{pH}$ & 6.6 & 6.3 & - \\
& $\mathrm{COD}\left(\mathrm{mg} \mathrm{L}^{-1}\right)$ & $753.0 \pm 5.5$ & $89.8 \pm 5.0$ & $88.1 \pm 6.2$ \\
& $\mathrm{BOD}_{5}\left(\mathrm{mg} \mathrm{L}^{-1}\right)$ & $81.6 \pm 4.2$ & $19.1 \pm 7.9$ & $76.6 \pm 4.8$ \\
& $\mathrm{pH}$ & 12.3 & 11.9 & - \\
\hline
\end{tabular}


According to Chatzisymeon et al., ${ }^{31}$ two mechanisms are involved in oxidation of pollutants by an electrochemical technique, namely direct anodic oxidation and indirect anodic oxidation. For direct anodic oxidation, pollutants are absorbed on anodic surfaces and destroyed by anodic electron transfer reactions. Indirect anodic oxidation involves the use of electrogenerated oxidants, such as $\mathrm{Cl}_{2}, \mathrm{OCl}^{-}, \mathrm{OH}^{*}, \mathrm{O}_{3}$ and $\mathrm{H}_{2} \mathrm{O}_{2}{ }^{31,32}$ The effect of $\mathrm{NaCl}$ presence on mineralisation of RB21 and synthetic textile effluent can be explained by referring to the following equations (Equations 7-10).

$$
\begin{aligned}
& \mathrm{H}_{2} \mathrm{O}+\mathrm{M}+\mathrm{Cl}^{-} \rightarrow \mathrm{M}[\mathrm{ClOH} \cdot]+\mathrm{H}^{+}+2 \mathrm{e}^{-} \\
& \mathrm{R}+\mathrm{M}\left[\mathrm{ClOH}^{\bullet}\right] \rightarrow \mathrm{M}+\mathrm{RO}+\mathrm{H}^{+}+\mathrm{Cl}^{-} \\
& \mathrm{H}_{2} \mathrm{O}+\mathrm{M}\left[\mathrm{ClOH}^{\bullet}\right]+\mathrm{Cl}^{-} \rightarrow \mathrm{M}+\mathrm{O}_{2}+ \\
& +\mathrm{Cl}_{2}+3 \mathrm{H}^{+}+4 \mathrm{e}^{-} \\
& \mathrm{H}_{2} \mathrm{O}+\mathrm{Cl}^{-} \rightarrow \mathrm{HOCl}+\mathrm{H}^{+}+2 \mathrm{e}^{-}
\end{aligned}
$$

In the presence of $\mathrm{NaCl}$, anodic water discharge resulted in the formation of chlorohydroxyl $\left(\mathrm{ClOH}^{\circ}\right)$ radi- cals on the anode surface (M) (Equation 7) which then oxidized the organic matter (R) (Equation 8). Furthermore, molecular $\mathrm{O}_{2}$ and free $\mathrm{Cl}_{2}$ can be formed by the reaction between $\mathrm{H}_{2} \mathrm{O}$ and $\mathrm{ClOH}^{*}$ radicals on the anode surface (Equation 9). Then, the resulting $\mathrm{Cl}^{-}$ions will react with water to form $\mathrm{OCl}^{-}$ions (Equation 10). The presence of large amount of electrogenerated $\mathrm{OCl}^{-}$ions in the bulk electrolysis provided better mineralisation efficiency ( $\mathrm{COD}$ and $\mathrm{BOD}_{5}$ reduction) as these electrogenerated species are beneficial in the degradation of organic pollutants in both samples. ${ }^{32}$

\section{6. Characterisation of $\mathrm{Co}_{47.5} / \mathrm{C}_{47.5}-\mathrm{PVC}_{5}$ Electrode}

Figure 6 shows the FESEM micrograph obtained from the morphological study of freshly prepared $\mathrm{Co}_{47.5} /$ $\mathrm{C}_{47.5}-\mathrm{PVC}_{5}$ composite electrode and after electrolysis of synthetic textile effluent by using $20 \mathrm{~V}$ applied voltage and 45 min electrolysis. Figure 6a shows the distribution of Co and $\mathrm{C}$ in the electrode can be seen clearly and are mixed quite well. However, the surface of the electrode slightly changes after electrolysis of RB21 solution in Figure 6 b.
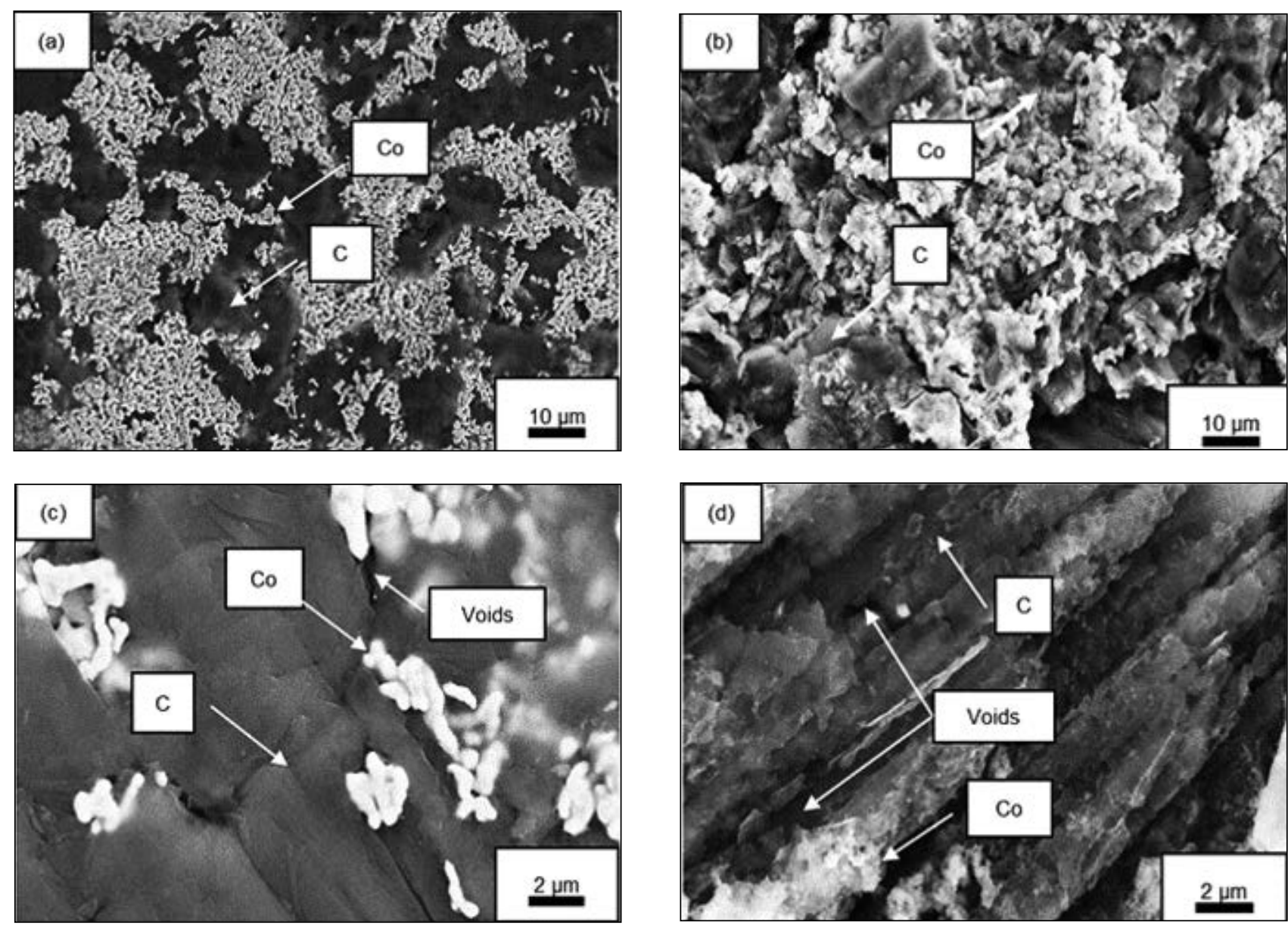

Figure 6. FESEM micrograph of $\mathrm{Co}_{47.5} / \mathrm{C}_{47.5}-\mathrm{PVC}_{5}$ electrode (a and c) fresh and (b and d) after electrolysis of synthetic textile effluent by using (a and b) 1000x and (c and d) 5000x magnification. ([RB21 $]_{o}=50 \mathrm{mg} \mathrm{L}^{-1} ;[\mathrm{NaCl}]=0.5 \mathrm{~mol} \mathrm{~L}^{-1} ; t=45 \mathrm{~min} ; E=20 \mathrm{~V}$ ). 
This is due to the degradation of the pollutant that occurred on the surface of the electrode. FESEM micrograph in Figure 6d shows a significant change in the surface of the electrode as compared to the freshly prepared electrode in Figure $6 \mathrm{c}$. The surface of the electrode was no longer smooth as compared to the freshly prepared electrode.

In addition, the surface of the prepared electrode showed the existence of voids that were not filled by the element and PVC. The presence of voids in the surface was very important as it increased the porosity characteristic of the electrode for a better electrochemical reaction. ${ }^{33}$ Figure $6 \mathrm{c}$ and $6 \mathrm{~d}$ show the presence of voids in the surface of each electrode before and after electrolysis, respectively. The presence of voids in the electrode surface after electrolysis showed that this electrode can be used for further electrolysis process without reducing its efficiency. TEM micrograph of freshly fabricated $\mathrm{Co}_{47.5} / \mathrm{C}_{47.5}-\mathrm{PVC}_{5}$ powder in Figure 7 indicated that the mixture formed agglomerate of different shapes. The Co particles can be identified due to their almost regular shape while the $\mathrm{C}$ was formed in an irregular shape as demonstrated in Figure 7.

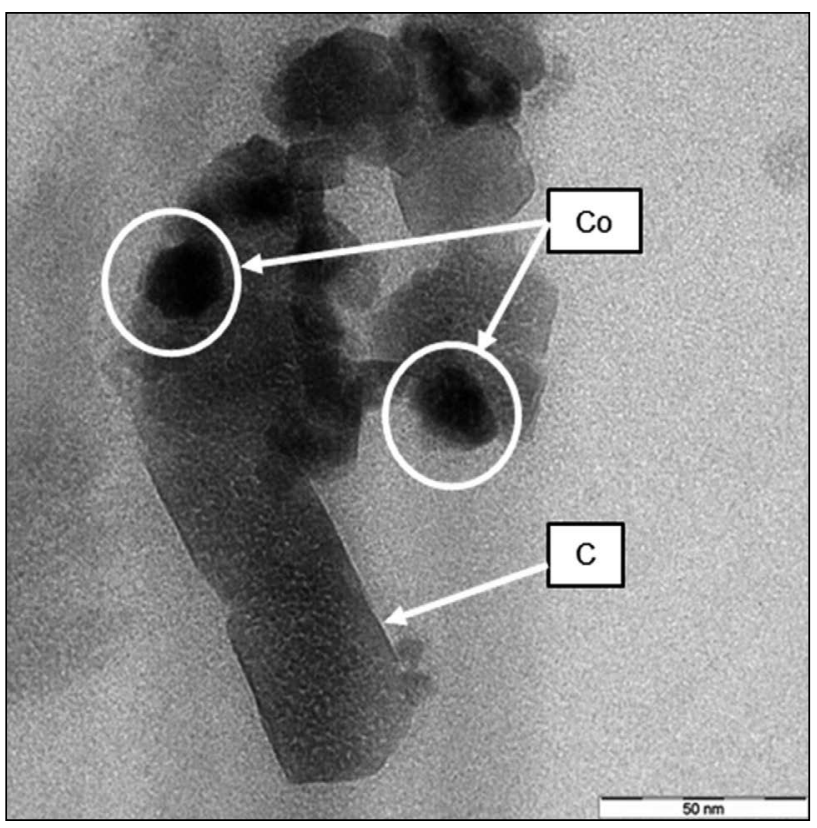

Figure 7. TEM micrograph of fresh $\mathrm{Co}_{47.5} / \mathrm{C}_{47.5}-\mathrm{PVC}_{5}$ powder by using 100,000x magnification.
The elemental composition of $\mathrm{Co}_{47.5} / \mathrm{C}_{47.5}-\mathrm{PVC}_{5}$ electrode was determined by using the EDX analysis and the results are presented in Table 3 . The results obtained proved that the prepared electrode contained $\mathrm{C}, \mathrm{Co}$, and $\mathrm{Cl}$. The presence of $\mathrm{Cl}$ elements was due to the use of PVC as a binder in the fabricated electrode. The composition of $\mathrm{C}$ for both samples (fresh and after electrolysis) was higher as compared to the Co due to the presence of polymeric carbon chain in PVC. Additionally, no significant changes were indicated by the weight percentage of each element in the fresh electrode and after the electrolysis of synthetic textile effluent. The difference in weight percentage may occur if the precipitate resulted after the electrolysis of synthetic textile effluent. The resulting precipitation was due to the corrosion of anode materials. However, no precipitate was obtained after the electrolysis of synthetic textile effluent. It can be concluded that PVC acts as a good binder agent between $\mathrm{C}$ and Co elements inside the electrode.

The surface area and pore size of fresh $\mathrm{Co}_{47.5} / \mathrm{C}_{47.5^{-}}$ $\mathrm{PVC}_{5}$ powder and after electrolysis of synthetic textile effluent were analysed by using Brunauer-Emmett-Teller (BET) method. The surface area of fresh $\mathrm{Co}_{47.5} / \mathrm{C}_{47.5}-\mathrm{PVC}_{5}$ and after electrolysis was $2.45 \mathrm{~m}^{2} \mathrm{~g}^{-1}$ and $6.89 \mathrm{~m}^{2} \mathrm{~g}^{-1}$, while the pore size was 12.53 to $9.19 \mathrm{~nm}$, respectively. The increased surface area and reduced pore size of the $\mathrm{Co}_{47.5} /$ $\mathrm{C}_{47.5}-\mathrm{PVC}_{5}$ powder after electrolysis were due to the adsorption of compounds on a solid surface. However, no significant difference was shown by the results obtained from the surface area and pore size of $\mathrm{Co}_{47.5} / \mathrm{C}_{47.5}-\mathrm{PVC}_{5}$ powder $(p>0.05)$. The results obtained were consistent with the observations made based on the FESEM micrographs. The pore sizes obtained from this study for freshly prepared $\mathrm{Co}_{47.5} / \mathrm{C}_{47.5}-\mathrm{PVC}_{5}$ and after electrolysis of synthetic textile effluent were referred to A mesopore type, as mentioned by Chen et al. ${ }^{34}$

\section{Conclusions}

The Co/C-PVC electrode with a composition ratio of 50:50 (known as the $\mathrm{Co}_{47.5} / \mathrm{C}_{47.5}-\mathrm{PVC}_{5}$ ) was considered to be the best metal/graphite-PVC composite electrode because it gives the highest decolourisation percentage of aqueous RB21. Optimum electrolysis conditions for the decolourisation of aqueous $\mathrm{RB} 21$ by using $\mathrm{Co}_{47.5} / \mathrm{C}_{47.5^{-}}$

Table 3. Elemental composition of $\mathrm{Co}_{47.5} / \mathrm{C}_{47.5}-\mathrm{PVC}_{5}$ electrode before and after electrolysis of $\mathrm{RB} 21$ solution. $\left([\mathrm{RB} 21]_{\mathrm{o}}=50 \mathrm{mg} \mathrm{L}^{-1} ;[\mathrm{NaCl}]=0.5 \mathrm{~mol} \mathrm{~L}^{-1} ; t=45 \mathrm{~min} ; E=20 \mathrm{~V}\right)$.

\begin{tabular}{lcccc}
\hline Element & \multicolumn{2}{c}{ Before electrolysis } & \multicolumn{2}{c}{ After electrolysis } \\
& Weight (\%) & Atomic (\%) & Weight (\%) & Atomic (\%) \\
\hline C & 77.37 & 93.96 & 75.25 & 91.38 \\
Co & 19.96 & 4.94 & 21.23 & 6.25 \\
Cl & 2.67 & 1.10 & 3.52 & 2.37 \\
\hline
\end{tabular}


$\mathrm{PVC}_{5}$ composite electrode was by using $20 \mathrm{~V}$ of applied voltage for $45 \mathrm{~min}$ of electrolysis time in the presence of $0.5 \mathrm{~mol} \mathrm{~L}^{-1} \mathrm{NaCl}$ solution as a supporting electrolyte. Under the optimum electrolysis conditions, $99.95 \%$ of RB21 decolourisation percentage was achieved. The $\mathrm{Co}_{47.5} / \mathrm{C}_{47.5^{-}}$ $\mathrm{PVC}_{5}$ composite electrode also showed high efficiency in the decolourisation of synthetic textile effluent by using similar optimum electrolysis conditions as mentioned above. This was further confirmed by $\mathrm{COD}$ and $\mathrm{BOD}_{5}$ analyses, in which a high percentage of decolourisation was achieved for COD and $\mathrm{BOD}_{5}$ analyses of RB21 solution and synthetic dye effluent. The electrode surface characterisation by using FESEM showed no significant changes in the presence of void on the electrode surface before and after RB21 electrolysis. The presence of voids on the electrode surface after electrolysis showed that this electrode can be used for further electrolysis process without reducing its efficiency. The results obtained for elemental composition by using EDX showed no significant changes in the composition of $\mathrm{C}, \mathrm{Co}$, and $\mathrm{Cl}$ elements in the prepared electrode before and after electrolysis of RB21 solution. This showed a good bonding between $\mathrm{C}$ and Co by using PVC as a binding agent.

\section{Aknowledgements}

The funding from Universiti Sains Malaysia through short-term grants (304-PKIMIA/6315104) and Universiti Teknologi MARA through LESTARI grant (600-IRMI/ MyRA 5/3/LESTARI (075/2017)) are gratefully acknowledged.

\section{Conflict of Interest}

The authors declare no conflict of interest.

\section{References}

1. A. R. Tehrani-Bagha, K. Holmberg, Materials 2013, 6, 580608. DOI: $10.3390 / \mathrm{ma} 6020580$

2. N. Ž. Šekuljica, N. Ž. Prlainović, A. B. Stefanović, M. G. Žuža, D. Z. Čičkarić, D. Ž. Mijin, Z. D. Knežević-Jugović, Sci. World J. 2015, 2015, 1-12. DOI:10.1155/2015/371625

3. V. Lopez-Grimau, M. C. Gutierrez, Chemosphere 2006, 62, 106-112. DOI:10.1016/j.chemosphere.2005.03.076

4. N. Nordin, S. F. Mohd Amir, M. R. Yusop, M. R. Othman, Acta Chim. Slov. 2015, 62, 642-651.

DOI:10.17344/acsi.2014.1264

5. S. Wijetunga, X. F. Li, C. Jian, J. Hazard. Mater. 2010, 177, 792-798. DOI:10.1016/j.jhazmat.2009.12.103

6. C. R. Holkar, A. J. Jadhav, D. V. Pinjari, N. M. Mahamuni, A. B. Pandit, J. Environ. Manage. 2016, 182, 351-366. DOI:10.1016/j.jenvman.2016.07.090
7. T. Robinson, G. McMullan, R. Marchant, P. Nigam, Bioresour. Technol. 2001. 77, 247-255. DOI:10.1016/S0960-8524(00)00080-8

8. C. A. Martinez-Huitle, E. Brillas, Appl. Catal. B-Environ. 2009, 87, 105-145. DOI:10.1016/j.apcatb.2008.09.017

9. M. Riera-Torres, M. C. Gutierrez, Chem. Eng. J. 2010, 156, 114-120. DOI:10.1016/j.cej.2009.10.006

10. F. Orts, A. I. del Río, J. Molina, J. Bonastre, F. Cases, J. Electroanal. Chem. 2018, 808, 387-394.

DOI:10.1016/j.jelechem.2017.06.051

11. J. Luo, Y. B. Wang, D. Cao, K. Xiao, T. Guo, X. Zhao, Chem. Eng. J. 2018, 343, 69-77. DOI:10.1016/j.cej.2018.02.120

12. Z. H. Mussa, F. F. Al-Qaim, M. R. Othman, M. P. Abdullah, J. Latip, Z. Zakria, J. Taiwan Inst. Chem. Eng. 2017, 72, 37-44. DOI:10.1016/j.jtice.2016.12.031

13. A. A. Najafpoor, M. Davoudi, E. R. Salmani, J. Env. Health Sci. Eng. 2017, 15, 1-11. DOI:10.1186/s40201-017-0273-3

14. M. Jović, D. Stanković, D. Manojlović, I. Anđelković, A. Milić, B. Dojčinović, G. Roglić, Int. J. Electrochem. Sci. 2013, 8, 168183.

15. M. A. Hasnat, J. A. Safwan, M. S. Islam, Z. Rahman, M. R. Karim, T. J. Pirzada, A. J. Samed, M. M. Rahman, J. Ind. Eng. Chem. 2015, 21, 787-791. DOI:10.1016/j.jiec.2014.04.013

16. N. Nordin, S. F. Mohd Amir, Riyanto, M. R. Othman, Int. J. Electrochem. Sci. 2013, 8, 11403-11415.

17. R. Salazar, M. S. Ureta-Zanartu, C. Gonzalez-Vargas, C. D. N. Brito, C. A. Martinez-Huitle, Chemosphere 2018, 198, 21-29. DOI:10.1016/j.chemosphere.2017.12.092

18. S. Alcocer, A. Picos, A. R. Uribe, T. Pérez, J. M. Peralta-Hernández, Chemosphere 2018, 205, 682-689. DOI:10.1016/j. chemosphere.2018.04.155

19. U. Morales, C. J. Escudero, M. J. Rivero, I. Ortiz, J. M. Rocha, J. M. Peralta-Hernández, J. Electroanal. Chem. 2018, 808, 180-188. DOI:10.1016/j.jelechem.2017.12.014

20. D. Rajkumar, B. J. Song, J. G. Kim, Dyes Pigm. 2007, 72, 1-7. DOI:10.1016/j.dyepig.2005.07.015

21. R. E. Palma-Goyes, J. Silva-Agredo, J. Vazquez-Arenas, I. Romero-Ibarra, R. A. Torres-Palma, J. Env. Chem. Eng. 2018, 6, 3010-3017. DOI:10.1016/j.jece.2018.04.035

22. M. R. Cruz-Díaz, E. P. Rivero, F. A. Rodríguez, R. Domínguez-Bautista, Electrochim. Acta. 2018, 260, 726-737. DOI:10.1016/j.electacta.2017.12.025

23. A. K. Verma, P. Bhunia, R. R. Dash, R. D. Tyagi, R. Y. Surampalli, T. C. Zhang, Clean (Weinh). 2015, 43, 767-774. DOI:10.1002/clen.201400256

24. APHA, AWWA, WPCF, Standard Methods for the Examination of Water and Effluents, American Public Health Association, Washington DC, USA, 1981, 525-535.

25. I. A. Sengil, M. Ozacar, J. Hazard. Mater. 2009, 16, 1369-1376. DOI:10.1016/j.jhazmat.2008.04.100

26. R. Galvan-Martinez, M. A. Baltazar, E. Mejia, M. Salaza, A. Contreras, R. Orozco-Cruz, Int. J. Electrochem. Sci. 2018, 13, 9561-9573. DOI:10.20964/2018.10.04

27. S. H. Oliveira, M. A. G. A. Lima, F. P. França, M. R. S. Vieira, P. Silva, S. L. U. Filho, Int. J. Biol. Macromol. 2016, 88, 27-35. DOI:10.1016/j.ijbiomac.2016.03.033 
28. X. Y. Huang, Y. Shen, X. Wei, M. Haapasalo, J. Endod. 2017, 43, 1847-1851. DOI:10.1016/j.joen.2017.06.033

29. H. Shakoor, M. Ibrahim, M. Usman, M. Adrees, M.A. Mehmood, F. Abbas, N. Rasool, U. Rashid, J. Dispersion. Sci. Technol. 2016, 37, 144-154.

DOI:10.1080/01932691.2015.1035387

30. M. C. Silva, A. D. Corrêa, M. T. S. P. Amorim, P. Parpot, J. A. Torres, P. M. B. Chagas, J. Mol. Catal. B: Enzym. 2012, 77, 9-14. DOI:10.1016/j.molcatb.2011.12.006
31. E. Chatzisymeon, N. P. Xekoukoulotakis, A. Coz, N. Kalogerakis, D. Mantzavinos, J. Hazard. Mater. 2006, 137, 998-1007. DOI:10.1016/j.jhazmat.2006.03.032

32. S. Raghu, C. A. Basha, J. Hazard. Mater. 2007, 139, 382-390. DOI:10.1016/j.jhazmat.2006.06.082

33. N. Nordin, M. R. Othman, Sains Malays. 2014, 43, 1761-1768. DOI:10.17576/jsm-2014-4312-10

34. S. Chen, J. Zhang, C. Zhang, Q. Yue, Y. Li, C. Li, Desalination 2010, 252, 149-156. DOI:10.1016/j.desal.2009.10.010

\section{Povzetek}

$\mathrm{V}$ tej raziskavi smo s tehniko mehanske tvorbe zlitin izdelali kompozitno elektrodo iz kobalta/grafita in polivinilklorida $\left(\mathrm{Co}_{47,5} / \mathrm{C}_{47,5}-\mathrm{PVC}_{5}\right)$. Novo elektrodo smo uporabili kot anodo, grafitno paličko pa kot katodo za razbarvanje vodne raztopine C. I. Reactive Blue 21 (RB21) in sintetične tekstilne odpadne vode, ki je vsebovala zmes azo in antrakinonskih barvil. Novoizdelana elektroda je pokazala visoko učinkovitost za razbarvanje RB21 v vodni raztopini (99,95\%) in sintetične tekstilne odpadne vode. To smo še nadalje potrdili z visokim deležem zmanjšanja (>75\%) KPK in $\mathrm{BPK}_{5}$ pri obeh obdelanih vzorcih. Elementna sestava $(\mathrm{C}, \mathrm{Co}$ in $\mathrm{Cl})$, določena s FESEM-EDX, ni bila bistveno različna med sveže izdelano elektrodo in po elektrolizi sintetične tekstilne odpadne vode. To je potrdilo visoko mehansko trdnost novoizdelane elektrode in visoko stopnjo vezave med C in Co zaradi uporabe PVC kot veziva. 